\title{
Research on English Majors' Intercultural Communication Competence in Business English Writing
}

\author{
Chunxia YANG \\ School of Foreign Languages, Wuhan Institute of Technology, Wuhan, 430205, China \\ email: yangchunxia2014@qq.com
}

Key words: ICC Competence, English Majors, BE Writing, Teaching Approach

\begin{abstract}
At present, Business English (BE) Writing spreads more widely into the fields of economy and international trade, which becomes a dispensable basic skill for people in the circle of business. Undoubtedly, this arouses the urgent need of teaching reforms in language classes. Students often express their thoughts according to native culture and Pragmatic rules, crossing and colliding with different cultural factors, so misunderstandings and conflicts occur, resulting in varying degrees of communication failures that affect the normal development of international business activities. This paper will aims at analyzing English majors' ICC (International Cultural Communication) knowledge by culture problems in their writing, cultivating students to become more smoothly, and professionals. The author tries to find applicable teaching methods and to meet requirements in National Curriculum for Business English BA Program as well, in order to provide some suggestions to the teaching of BE writing.
\end{abstract}

\section{Introduction}

Since its joining in World Trade Organization, China's communication and cooperation with the international world has greatly expanded. [1] China integrates its business into the world economy more and more closely and comprehensively. With more communication and the open environment, the expansion of the international business calls for more talents who can help to bridge the giant gaps between languages and cultures and can make efficient communications in the business world. For English majors, they should not only master the knowledge of English, but also master the knowledge of Business. [2] [3] It would be a great advantage for university students to have a good command of Business English Writing skills. Business English is the English which is specifically used in business. Business English Writing, as a very important approach of foreign communication, is of vital importance, whose quality decides the success of a business transaction to a large extent. [4] In the huge wave of economic development, it becomes the tool for people to express their opinions, convey meanings and communicate in language it realizes the function to promote economy and reflects our economic life as a special language phenomenon. It is urgent for Business English teachers to raise the students' ICC competence into the BE writing. [5] [6] ICC competence in this paper requires that the students should have the global awareness to understand the international conventions or to grasp the international culture, in order to take international business in accordance with the international conventions and deal with all kind of relationship and communicate and work in English. [7] [8] In the practical teaching of BE writing, the author finds that the students who majored in English lack of cultural awareness in their writing. So the author strongly suggests that it is necessary to train students' cultural awareness and ICC competence in BE writing. [9] 


\section{Methodology}

\section{A. Participants}

The subjects in this research are 100 juniors who majored in English in Wuhan Institute of Technology. They have studies English for two years in the university Their English writing abilities are at the same level. Their ages are from 19 to 22 years old.

\section{B. Research Instrument}

In this study, qualitative and quantitative methods are adopted. Qualitative approach is used to discuss the cultural knowledge of business writing. To ensure the objectivity of the research, none of the participants are informed that they are in a teaching research. [10] It is used to demonstrate the frequencies of each language point in these letters. The author does this research from three main aspects: salutation, signature and complementary close.

\section{Results and Discussion}

Based on the culture problems in their writing, the author adopted a research on ICC competence in their BE writing and analyzed the textbook Business English Writing which aims at analyzing the knowledge culture and communicative culture in this course.

\section{A. Prerequisites before Data Analysis}

Table 1 The Score Distribution of the Assignments

\begin{tabular}{|l|l|l|l|l|l|l|l|l|}
\hline Score & $6-6.5$ & $6.6-7$ & $7.1-7.5$ & $7.6-8$ & $8-8.5$ & $8.6-9$ & $9.1-9.5$ & $9.6-10$ \\
\hline Number & 7 & 12 & 10 & 10 & 15 & 21 & 15 & 10 \\
\hline
\end{tabular}

Table1 is used to explain the distribution of the score and make a preparation to do further research.

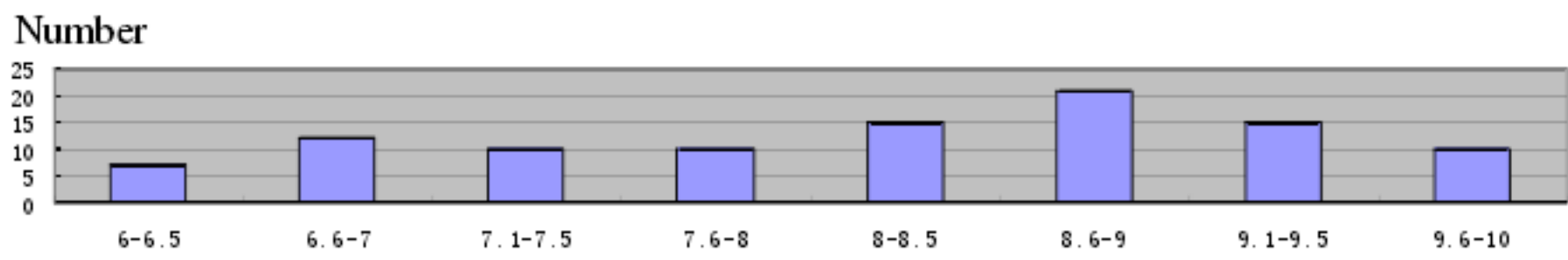

Figure 1 Histogram of Scores with Normal Curve

Seen from figure 1, the data comply with the normal distribution; therefore, which used to confirm that all the data comply with the normal distribution.

\section{B. Results Concerning Analysis of the Letters}

BE letters typically include seven parts which include heading, salutation, body, date, inside address, complimentary close, and signature block. In this research, three of the elements which are salutation, complimentary close, and signature, will be chosen, and knowledge culture and communication culture will also be analyzed as well.

a. Analysis of Salutation and Complimentary Close

In BE writing, both salutation and complimentary close involve intercultural communication information. 
Table 2 The Salutation and Complimentary Close in the letters

\begin{tabular}{|c|c|c|}
\hline Context & Salutation & Complimentary close \\
\hline $\begin{array}{l}\text { You don't know the name } \\
\text { of the recipient }\end{array}$ & $\begin{array}{l}\text { Dear Sir } \\
\text { Dear Madam } \\
\text { Dear Sir/Madam } \\
\text { Dear Sirs } \\
\text { Gentlemen (US only) }\end{array}$ & $\begin{array}{l}\text { Yours faithfully (UK only) } \\
\text { Sincerely yours (US) } \\
\text { Yours truly (US) } \\
\text { Sincerely (US) } \\
\text { Yours sincerely (US) }\end{array}$ \\
\hline $\begin{array}{l}\text { You know the name of the } \\
\text { recipient }\end{array}$ & $\begin{array}{l}\text { Dear Mr. Smith } \\
\text { Dear Mr. and Mrs. Smith } \\
\text { Dear Ms Smith (either } \\
\text { married or unmarried) } \\
\text { Dear Mrs. Smith (married) } \\
\text { Dear Miss Smith (single) }\end{array}$ & Yours sincerely \\
\hline $\begin{array}{l}\text { You know the recipient } \\
\text { quite well }\end{array}$ & $\begin{array}{l}\text { Dear Bill } \\
\text { Dear Alice }\end{array}$ & $\begin{array}{l}\text { Best regards/Regards } \\
\text { Best wishes }\end{array}$ \\
\hline
\end{tabular}

From the table 2, we can see some Chinese students tend to write Director Zhang, Manager Li and so on in the part of salutation. The reason of making mistakes is because of lack of the cultural awareness. And the same mistakes are also be made in complimentary close. Thus the author will do a further research about the two aspects written in the letters.

Table 3 Percentage of Different Salutation in the Letters

\begin{tabular}{|l|l|l|}
\hline Salutation & Number & Percentage \\
\hline Dear Mr. Schmidt & 60 & $60 \%$ \\
\hline Dear Martin Schmidt & 21 & $21 \%$ \\
\hline Dear Mr. Martin Schmidt & 3 & $3 \%$ \\
\hline Dear Martin & 2 & $2 \%$ \\
\hline Dear Schmidt & 2 & $2 \%$ \\
\hline Others & 12 & $12 \%$ \\
\hline Total & 100 & $100 \%$ \\
\hline
\end{tabular}


Table 4 Percentage of Different Complimentary Cloze in the Letters

\begin{tabular}{|l|l|l|}
\hline Complimentary close & Number & Percentage \\
\hline Yours sincerely & 86 & $86 \%$ \\
\hline Sincerely yours & 6 & $6 \%$ \\
\hline Yours & 6 & $6 \%$ \\
\hline Sincerely & 2 & $2 \%$ \\
\hline Total & 100 & $100 \%$ \\
\hline
\end{tabular}

Table 3 and Table 4 are the data of the salutation and complimentary. We can see that only $60 \%$ of the students know how to use the proper salutation accordingly. While $2 \%$ of them use Dear Martin, although it is not totally wrong, it is still not appropriate to be used in such case. Since $86 \%$ of the student writers know how to use the suitable complimentary close, so the author can conclude that most of them know how to use them properly.

b. Signature

In some special cases, the person should be prepared to take legal advice when he writes the letter of apology. Thus, the signature is greatly significant in such a business letter. In this case, the signature is often required to be written by hand. In the following part, it is his/her typed-out name. His/her title or position in the organizations is often given. While looking through these letters, some of the students still neglect the point. Later, the signature will be analyzed in the following part.

Table 5 The Percentage of Different Signature in The Letters

\begin{tabular}{|c|c|c|c|c|c|}
\hline & Class 1 & Class 2 & Class 3 & Total & percentage \\
\hline Handwritten signature & 26 & 27 & 28 & 81 & $81 \%$ \\
\hline Lack of handwritten signatur & 6 & 6 & 7 & 19 & $19 \%$ \\
\hline
\end{tabular}

Seen from the table 5, we can see that most of them understand the information that it is necessary to use handwritten signature. $81 \%$ of the participants have used handwritten signature, while $19 \%$ participants have still signed Mr. Lang or other misused names. The problem is that although they know this knowledge, they can not use the proper form of name to be signed. Thus it is still necessary and urgent for the teachers to focus on this point in the BE writing class.

\section{Conclusion}

After the experiment, it is found that there is a lot of work can be done in English teaching and learning. However, it is impossible to do all work in a short time of experiment. [11] The correlation between the students' ICC competence and the BE writing has been stated by analyzing the Letters in the study, which is just applied to the small group of participants. [12] [13] From the whole study, it is clear that ICC competence is of great significance in BE writing, thus it is quite urgent and necessary to strengthen business-oriented learners' intercultural communication competence. The author also hopes that this study will generate further researches on the studies of intercultural communication competence in China. Furthermore, the author suggested that colleges are encouraged to increase courses about intercultural communication to the curriculum, and offer such courses to business-oriented majors. Although the research questions of this study have been 
answered, more questions about how to take the advantage of ICC competence to improve students' English writing proficiency will come out to be studied in teaching practice.

\section{References}

[1] Glenn S.Levine. Global Simulation: A Student - Centered, Task - Based Format for Intermediate Foreign Language Courses[J]. Foreign Language Annals . 2008 (1)

[2] Anthony Bruton. Task-based language teaching: For the state secondary FL classroom?[J]. Language Learning Journal . 2005 (1)

[3] Libby V. Morris. Editor's Page: Exploring the Learning Paradigm[J]. Innovative Higher Education . 2004 (2)

[4] Victoria Rodrigo, Stephen Krashen, Barry Gribbons. The effectiveness of two comprehensible-input approaches to foreign language instruction at the intermediate level[J]. System . 2003 (1)

[5] Bailey,K.M.Working for Weshbeck:A Review of the Washback Concept in Language Testing. Language Testing . 1996

[6] Guo-Ming Chen. Relationships of the dimensions of intercultural communication competence[J]. Communication Quarterly . 1989 (2)

[7] Prue Holmes, Gillian O’Neill. Developing and evaluating intercultural competence: Ethnographies of intercultural encounters[J]. International Journal of Intercultural Relations . 2012 (5)

[8] David Matsumoto,Jeffery A. LeRoux,Yvette Robles, Guillermo Campos. The Intercultural Adjustment Potential Scale (ICAPS) predicts adjustment above and beyond personality and general intelligence[J]. International Journal of Intercultural Relations . 2007 (6)

[9] Uwe Baumann, Monica Shelley. Distance learners of German and intercultural competence[J]. Open Learning: The Journal of Open and Distance Learning . 2006 (3)

[10] Lily A. Arasaratnam, Marya L. Doerfel. Intercultural communication competence: Identifying key components from multicultural perspectives[J]. International Journal of Intercultural Relations . $2005(2)$

[11] Alex Casillas,Steven B. Robbins. Test Adaptation and Cross-Cultural Assessment From a Business Perspective: Issues and Recommendations[J]. International Journal of Testing . 2005 (1)

[12] Lies Sercu. Assessing intercultural competence: a framework for systematic test development in foreign language education and beyond[J]. Intercultural Education . 2004 (1)

[13] Goodenough Ward H.Cultural Anthropology and Linguistics. Language in Culture and Society: A Reader in Linguistics and Anthropology . 1964 